\section{УДК: 616.62-007.46-089}

\section{Т.И. Даньшин, В.Д. Письменный, И.С. Максакова, Д.А. Янчук}

Национальный медицинский университет им. А.А. Богомольца,

Национальная детская специалированная больница «Охматдет»

(г. Киев, Украина)
СПОСОБ ХИРУРГИЧЕСКОГО ЛЕЧЕНИЯ ЭКСТРОФИИ МОЧЕВОГО ПУЗЫРЯ
Ключевые слова: экстрофия мочевого пузыря, искусственный мочевой пузырь, хирургическая коррекиия, раздельная дефекация и мочеиспускание

\begin{abstract}
Резюме. Операции по коррекичи экстрофии мочевого пузыря являются реконструктивно-пластическими и должны выполняться на базе детских хирургических иеентров. Наиболее патогенетически обоснованной является пластика мочевого пузыря местными тканями, но для ее выполнения необходимы определенные условия. Если пластика местными тканями не выполнима или отдаленные результаты ее неудовлетворительные, операцией выбора является предложенный метод хирургической коррекиии порока. Проведен анализ результатов лечения у 22 детей по разработанному способу. Данный способ является альтернативным в хирургическом лечении экстрофии мочевого пузыря.
\end{abstract}

Несмотря на более чем вековую историю, проблема лечения экстрофии мочевого пузыря (ЭМП) остается актуальной и на сегодняшний день $[1,4]$.

Это обусловлено сложностью порока, его вариабельностью и остающимся высоким процентом неудовлетворительных результатов лечения. Окончательно не решены вопросы выбора сроков и способов операции как у новорожденных, так и у детей старшего возраста $[3,6]$.

В настоящее время признано два основных метода в хирургическом лечении порока: первый - пластика мочевого пузыря местными тканями; второй метод направлен на деривацию мочи в кишечный тракт и объединяет 3 группы операций: без разделения тока мочи и кала, с частичным и полным отведением мочи [5].

Наиболее патогенетически обоснованной является операция с использованием местных тканей при формировании мочевого пузыря [1].

Однако, для выполнения этой операции необходим достаточный размер пластинки мочевого пузыря. Кроме того, операция должна выполнятся в первые дни жизни ребенка до развития вторичных изменений в стенке мочевого пузыря [7]. Обязательным условием является устранение диастаза лонных костей [2]. Операция является сложной, поэтому ребенок должен иметь достаточную массу тела и не иметь тяжелых сочетанных пороков. В тех случаях, когда новорожденные не соответствуют этим требованиям, выполняют операции по кишечной деривации мочи [8].

В клинике разработан (патент № 30906 от 11.03.2008) и внедрен способ хирургического лечения ЭМП. Операция выполняется следующим образом: нижнесрединная лапаротомия с иссечением пластинки мочевого пузыря и пересечением мочеточников у их устья. Мобилизация сигмовидной кишки с учетом длины, необходимой для низведения на промежность. Сигмовидную кишку пересекаем, проксимальный конец заглушаем. Имплантируем мочеточники инвагинационным способом в просвет прямой кишки, которую затем заглушаем двухрядным швом.

На уровне переходной складки брюшины рассекаем серозно-мышечный слой прямой кишки по передней полуокружности. Производим демукозацию прямой кишки в дистальном направлении почти по всей полуокружности, оставляя неотделенной узкую полоску шириной не более 1 см на 5-6 часов по циферблату (рис.1).

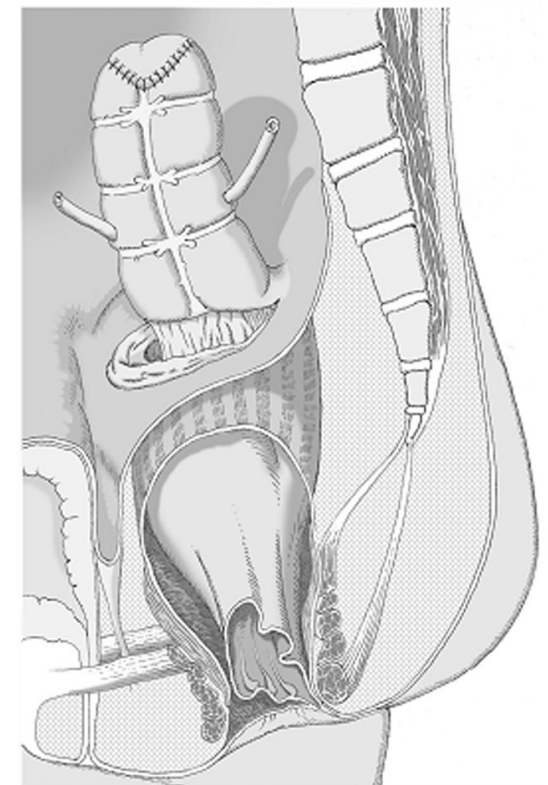

Рис.1. Сигмовидная кишка пересечена, в нее имплантированы мочеточники, резервуар заглушен, выполнена демукозация прямой кишки в дистальном направлении. 
Со стороны промежности отделенную слизистую оболочку иссекаем конусом вниз и сшиваем края непрерывным швом (рис.2).

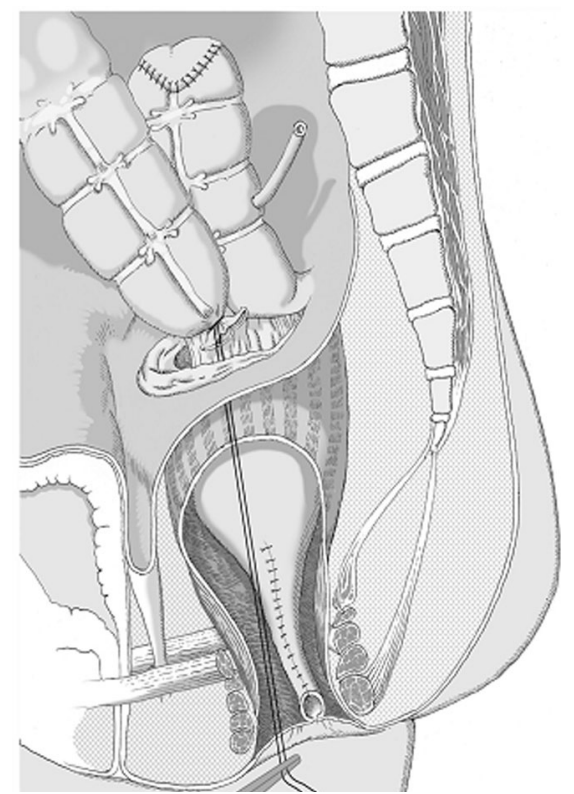

Рис.2. Иссечен избыток отделенной слизистой прямой кишки, сформирована уретра, начато низведение толстой кишки.

Канал неоуретры на протяжении анального канала должен быть шириной не более 1 см. Сигмовидную кишку низводим интраректально (рис.2,3) и накладываем кожно-слизистые швы по окружности ануса и сформированной уретры (рис.4).

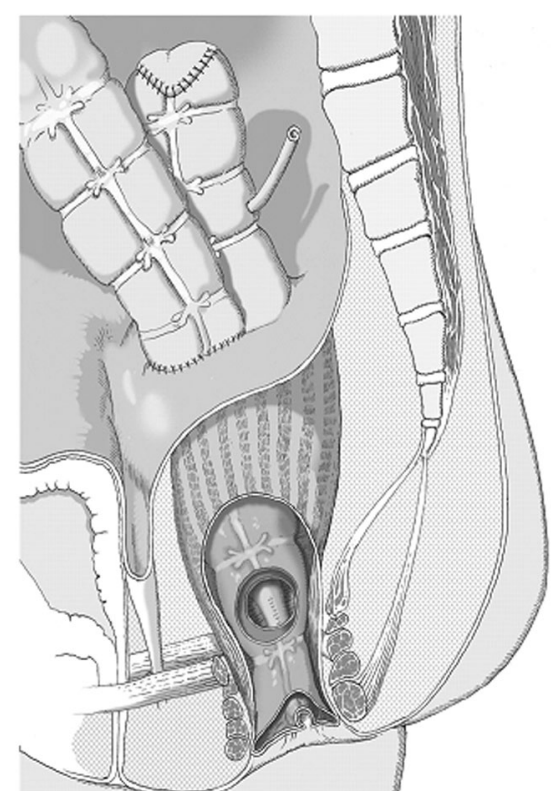

Рис.3. Сигмовидная кишка низведена на промежность интраректально.

Со стороны брюшной полости края рассеченной мышечной оболочки прямой кишки подшиваем к низведенной кишке и перитонизируем тазовое дно. По ходу операции создаваемый резервуар обрабатываем 1-2 \% р-ром повидон-йода.

Таким образом, вновь сформированная уретра и низведенная толстая кишка находятся внутри сфинктерного комплекса прямой кишки, что обеспечивает функцию держания мочи и кала и предотвращает их смешивание (рис. 5).

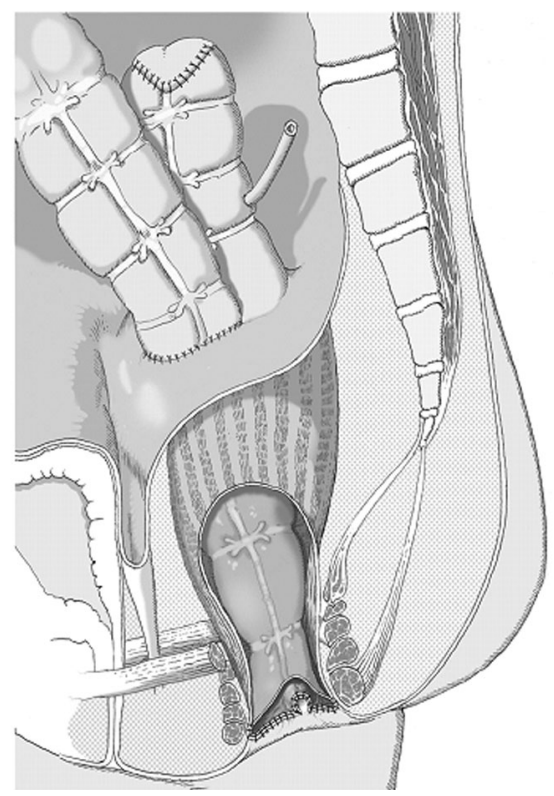

Рис.4. Края низведенной кишки подшиты к кожно-слизистому стыку по окружности ануса и неоуретры.

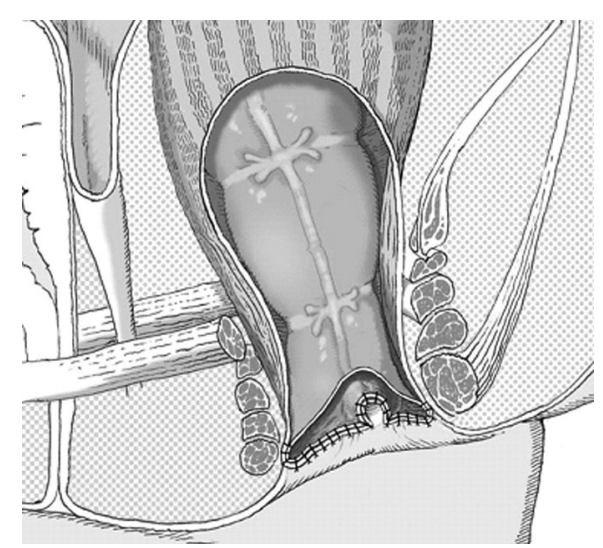

Рис.5. Низведенная кишка и сформированная уретра находятся внутри сфинктерного комплекса прямой кишки.

За период с 2002 по 2014 года в клинике на лечении по поводу ЭМП находилось 22 ребенка. Первично по разработанному способу оперированы 14 детей в возрасте от 8 мес до 3 лет. Повторная реконструктивная операция проведена у 8 пациентов из-за неудовлетворительных результатов ранее предпринятого лечения. У 5 из них в периоде новорожденности выполнена пластика мочевого пузыря местными тканями.

Трое детей оперированы в других лечебных учреждениях в возрасте от 3 до 9 лет: у 2-х выполнена операция А.В.Мельникова; у 1-го операция Михельсона-Терновского.

Результаты лечения оценивали через 1 год после операции. Отдаленный катамнез изучен у 12 детей на протяжении 7 лет. Учитывали жалобы и общеклинические результаты: функцию держания мочи и кала, наличие или отсутствие смешивания мочи и кала, состояние мочеточников и почек по данным УЗИ и экскреторной урографии; результаты данных анализов крови и мочи. 
Последние годы производим эндоскопический осмотр полости сформированного мочевого пузыря.

Из обследованных пациентов у 8 результаты оценены как хорошие. Эти дети удерживают мочу и кал в дневное и ночное время. Акт дефекации у них не более трех раз в день. Мочеиспускание происходит при дефекации и раздельно до 5-6 раз в день, при этом трое детей чувствовали раздельный позыв к мочеиспусканию. При ректальном исследовании сфинктер у них тоничен, ампула прямой кишки пустая. При осмотре в зеркалах отверстие неоуретры на 6 часах, пропускает свободно катетер, полученная при этом моча прозрачная с небольшим количеством слизи. При УЗИ и данным экскреторной урографии нарушений в структуре и функции почек не выявлено.

У 4 детей результаты признаны удовле- творительными. Эти дети удерживают мочу и кал, хотя у 2 из них периодически отмечается частое подтекание мочи в ночное время, у 1 ребенка 4-х лет подтекание мочи было более частое. Раздельный позыв на дефекацию и мочеиспускание не отмечен. У 1 ребенка спустя 2,5 года после операции обнаружен камень в сформированном мочевом пузыре, что потребовало его оперативного удаления. У 1 ребенка выявлен односторонний пузырно-мочеточниковый рефлюкс, в связи с чем выполнена антирефлюксная операция.

Таким образом, при невозможности пластики мочевого пузыря местными тканями или неудовлетворительных результатах коррекции, методом выбора дальнейшего лечения может быть разработанный способ. Данный способ обеспечивает надежное держание мочи и кала и предотвращает их смешивание.

\section{Література}

1. Аверин А.В. Лечение экстрофии мочевого пузыря у новорожденных / А.В. Аверин // Детсткая хирургия. -2004. - №6 - C. 13-16.

2. Аверин А.В. Роль остеотомии тазового кольца в хирургическом лечении экстрофии мочевого пузыря/А.В. Аверин, А.М. Соколовский // Детсткая хирургия. - 2009. - №3 - С. 12-14.

3. Ашкрафт К.У. Детская хирургия / К.У. Ашкрафт, Т.М. Холдер. - 1999. - С. 11-25.

4. Баиров Г.А. Современные методы хирургического лечения экстрофии мочевого пузыря / Г.А. Баиров, И.Б. Осипов // 19-й Всесоюзный съезд хирургов. - Ташкент, 1986. - С. 83-84.

5. Исаков Ю.Ф. Детская хирургия. Национальное руководство / Ю.Ф. Исаков, А.Ф. Дронов. - М., 2009. - С. $609-611$.

6. Рудин Ю.Э. Способы коррекции экстрофии мочевого пузыря у детей / Ю.Э. Рудин, Д.В. Марухненко // Детская хирургия. - 2009. - №4. - С. 18-23.

7. Brock III J.W. Bladder extrophy / J.W. Brock III, J.A. O’Neil, Jr // Pediatric Surgery. - 1998.-Vol.2. - P.1709-1759.

8. Stein R. Hypospadias and bladder extrophy // R.Stein, J.W. Thuroff // Curr. - Opin. Urol. - 2002.-№3.-P. 195-250.

\section{СПОСІБ ХІРУРГІЧНОГО ЛІКУВАННЯ ЕКСТРОФІЇ СЕЧОВОГО МІХУРА}

\author{
T.I. Даньшин, В.Д. Письменний, \\ І.С. Максакова, Д.О. Янчук
}

\section{Національний медичний університет ім. О.О. Богомольщя, \\ Національна дитяча спеціалізована лікарня «Охматдит», (м. Київ, Україна)}

Резюме. Операції з приводу корекції екстрофії сечового міхура $є$ реконструктивно-пластичними і повинні виконуватись на базі дитячих хірургічних центрів. Найбільш патогенетично обумовленою $є$ пластика сечового міхура місцевими тканинами, але для її виконання необхідні певні умови. Якщо пластика місцевими тканинами не може бути виконана або віддалені результати є незадовільними, операцією вибору є запропонований метод хірургічної корекції вади. Проведено аналіз результатів лікування у 22 дітей за розробленим методом, який $є$ альтернативним у хірургічному лікуванні екстрофії сечового міхура.

Ключові слова: екстрофія сечового міхура, штучний сечовий міхур, хірургічна корекція, роздільна дефекація та сечовипускання.

\section{THE METHOD OF SURGICAL TREATMENT OF BLADDER EXSTROPHY}

\author{
T. Danshin, V. Pysmenny, \\ I. Maksakova, D. Yanchuk \\ O. Bohomoltsia National \\ Medical University \\ National Children's Specialized \\ Hospital «Okhmatdyt», \\ (Kyiv, Ukraine)
}

Summary. Operative correction of bladder exstrophy is reconstructive and must be carried out on the basis of children's surgical centers. Most pathogenetically substantiated is a bladder plastic by local tissues, but its implementation requires certain conditions. If plastic by local tissues is not possible, or long-term results of its are unsatisfactory, the proposed method of operation is the choice of surgical correction. The analysis of the results of treatment in 22 children developed method was conducted. This method is an alternative in surgical treatment of bladder extrophy.

Keywords: bladder exstrophy, artificial bladder, surgical correction, separate defecation and urination. 